\title{
A Prospective Interventional Study to Compare Two Weeks versus Four Weeks Gap in 'Quad Shot' Regimen in Locally Advanced Head and Neck Cancers
}

\author{
Charan Singh*, Sandeep Jain
}

Department of Radiation Oncology (Radiotherapy) SMS Medical College, Jaipur, Rajasthan, India

DOI: $10.36347 /$ sjams.2020.v08i06.003

| Received: 05.05.2020 | Accepted: 23.05.2020 | Published: 10.06.2020

*Corresponding author: Dr. Charan Singh

Abstract

Original Research Article

Background: Palliative radiotherapy is an effective option for incurable head and neck cancers. It is delivered by a variety of fractionation schedules. The 'QUAD SHOT' (RTOG 8502) palliative radiotherapy regimen offers an overall high palliative response in patients with locally advanced head and neck cancers. The aim of the present study was comparing the outcome of two versus four weeks gaps between consecutive cycles of radiotherapy in terms of toxicity, compliance, tolerability and loco-regional control, with reduction of overall treatment time. Methodology: Total 100 subjects were treated on cobalt teletherapy machine. This regimen consists of $3.7 \mathrm{~Gy}$ twice-daily fractions given over two consecutive days per cycle with a rest period of 2 and 4 weeks between the 3 prescribed cycles for a total dose of 44.4 Gy. Sample size is 50 cases in each group. This study was conducted at Department of Radiation Oncology, S.M.S Medical College Jaipur, and Rajasthan. Results: Overall palliative response is $57 \%$ in the study group while $62 \%$ in control group which is statistically non significant in both groups. Incidence of acute dermatitis and acute mucositis were higher in study group, it was statistically significant $(\mathrm{p}=0.034)$ and $(\mathrm{p}=0.015)$ respectively but manageable with supportive measures like intravenous fluid, medication and adequate nutrition. Other radiation reactions were comparable and statistically non-significant $(p>0.05)$ in both treatment arms. Conclusion: On the basis of results it may be conclude that Two weeks gap in 'QUAD SHOT' (RTOG 8502) radiotherapy regimen can be used in locally advanced Head and Neck cancers to shorten overall treatment time without compromising overall palliation achieved in terms of symptomatic response and locoregional control with manageable toxicities.

Keywords: Palliative radiotherapy, LAHNC, Symptomatic response.

Copyright @ 2020: This is an open-access article distributed under the terms of the Creative Commons Attribution license which permits unrestricted use, distribution, and reproduction in any medium for non-commercial use (NonCommercial, or CC-BY-NC) provided the original author and source are credited.

\section{INTRODUCTION}

Head \& neck cancer is the most common cancer among Indian population [1]. According to Globocon 2018 the incidence is $4.6 \%$ out of which lip and oral cavity constitute $2.0 \%$ with $3,54,864$ cases, nasopharynx $0.7 \%$ with $1,29,079$ cases, oropharynx $0.5 \%$ with 92,887 cases, hypopharynx $0.4 \%$ with 80,608 cases, larynx $1.0 \%$ with $1,77,422$ cases, salivary glands and others $0.3 \%$ with 52,799 cases[2]. Head and neck malignancies constitute approximately $16.70 \%$ of all cancers in our department of Radiation Oncology, SMS medical college \& Hospital, Jaipur Rajasthan. Tobacco, Alcohol consumption, Betel Nut Chewing, Marijuana abuse, Occupational Exposure, UV Light Exposure, Diet, Genetic Factor, and viruses and various other etiologic and risk factors are responsible for Head and Neck cancers [3-11]. Because of critical location of most of the head and neck squamous cell neoplasms, they interfere with breathing, eating and phonation, thus affecting the quality of life. Surgery and/or chemotherapy and radiotherapy are traditionally the mainstay of the treatment of locally advanced head and neck cancers. Altered fractionation radiotherapy improves survival in patients with head and neck squamous cell carcinoma (HNSCC)[12].

In our department of Radiation Oncology, SMS medical college \& Hospital, Jaipur Rajasthan most of the patients present as locoregionally advanced form (Locoregionally Advanced Head and Neck Cancer: LAHNC) requiring Concurrent Chemo-Radio-Therapy (CCRT) as the standard of care [13, 14]. However, many such patients are not suitable candidates for definitive Radiotherapy (RT). A cyclical hypofractionated palliative radiotherapy regimen, originally devised for advanced pelvic malignancies (RTOG 8502), has been successfully adapted for palliative treatment of head and neck cancers. This regimen consists of 3.7 Gy twice-daily fractions given 
over two consecutive days per cycle with a rest period of 2 to 4 weeks between the 3 prescribed cycles for a total dose of $44.4 \mathrm{~Gy}$. As each cycle consists of four fractions, this regimen is popularly known as the 'QUAD SHOT. The present study will be comparing the outcome of two versus four weeks gap between consecutive cycles of radiotherapy in terms of toxicity, compliance, tolerability and loco-regional control, with reduction of overall treatment time.

\section{Material \& Methods}

This study was conducted at Department of Radiation Oncology, S.M.S Medical College Jaipur, and Rajasthan, India.

\section{Study period}

Patient recruitment was started from June 2018 to June 2019 just after getting approval of the institutional Ethical Committee.

\section{Study universe}

Locoregionally advanced head and neck cancer patients attending department of Radiation Oncology, S.M.S. Medical College \& Attached Group of Hospitals, Jaipur. All patients to be included in the study were histopathologically proven.

\section{Sample size}

Sample size was calculated as per $65 \%$ rate of palliative care achieved given in seed article[8] with $95 \%$ of confidence interval, $80 \%$ power and $10 \%$ absolute error. Following above assumption, 41 cases in each arm are required as sample size for statistical analysis of present study. Therefore sample size was increased to 50 cases in each group as final sample size for present study expecting $25 \%$ dropouts/ lost to follow up/ accretion in 6 months follow up period.

\section{Method of randomization}

Patients were randomized by Chit in box method with replacement.

\section{Assessment of toxicities}

Patients were evaluated for toxicity every two weeks during radiation and thereafter during follow-up at initially monthly for three months and subsequently at three months intervals. Toxicities appearing within 90 days of the start of therapy were defined as acute toxicities. Skin reaction, mucositis, dysphagia, and xerostomia were graded according to the Radiation Therapy Oncology Group (RTOG) acute and chronic radiation morbidity criteria, whereas haematological toxicities were graded according to the National Cancer Institute's Common Terminology Criteria for Adverse Events (CTCAE) version 4.03.

\section{Assessment of tumour response:}

Symptomatic response evaluation was done during the treatment and locoregional control was evaluated after 3 months of completion of treatment based on clinical examination and CECT/MRI of head and neck. Biopsy or fine-needle aspiration cytology was taken from any suspicious clinical and or radiological residual tumour at primary site and/or nodal area. Patients was then be categorized as per RECIST Criteria (Response Evaluation Criteria in Solid Tumours) version 1.1.

\section{Inclusion criteria}

Histopathologically confirmed malignant epithelial neoplasm of head and neck

- AJCC stage III -IV

- Patients with low performance status (PS>2) and/or not suitable for definitive treatment.

- $\quad$ Either sex

- Age 18-80 years

- Who gave written informed consent

\section{Exclusion criteria}

- Patients with history of prior radiotherapy to Head and Neck region

- Post operative patients

- Patients with double malignancy.

- Pregnant and lactating women.

- Patients with comorbidities.

\section{Radiation Technique}

- All patients were treated on cobalt teletherapy machine by 2-dimensional conventional radiation therapy technique.

- Patients were treated in supine position with appropriate immobilization.

- Treatment was delivered with parallel opposed/ ipsilateral field depending up on the target.

- The radiotherapy prescription was 3.7 Gy twice-daily fractions with minimum gap of 6 hours given over two consecutive days to a total of 14.8 Gy per cycle.

- Treatments were delivered for 3 cycles.

- In study group, each cycle was repeated at 2 weeks interval.

- In control group, each cycle was repeated at 4 weeks interval.

\section{ObSeRVATions \& Results}

The age range of the study Population was 2579 years and 30-80 years of the control group. In groups studied majority of patients were males (48 in the study group and 45 in control group) and rest were females (2 in the study group and 5 in control group) in table-1. In the present study, it is observed that most common site of primary tumor is oral cavity with $25(50 \%)$ patients in the study group and $20(40 \%)$ in the control group (Table-2). In the population studied squamous cell carcinoma was most common histology. The Most common histopathology was moderately differentiated squamous cell carcinoma (MDSCC) with $34 \%$ in the study group and $36 \%$ in the control group (Table-3). Among the population studied $26 \%$ patients were 
having stage IVB and $69 \%$ were having IVA disease. The rest $5 \%$ patients were having III stage disease (Table-4). The table-5 shows symptomatic response which is objective in term of relief in pain, insomnia, trismus, placement of feeding Ryle's tube and history of weight loss. In the study group pain relieved in $72 \%$, Insomnia 56\%, Trismus 57\%, reduction in placement of Ryles tube in $48 \%$ \& history in weight loss in $52 \%$. In control group pain relieved in $64 \%$ insomnia $60 \%$,
Trismus $60 \%$ Ryle's intubation $70 \%$ and history of weight loss $56 \%$.

Even though the symptomatic response was statistically non-significant in both the groups. The table-6 shows incidence of overall palliation achieved in both treatment groups. $57 \%$ overall palliation achieved in the study group was not statistically difference $(p=0.834)$ from the $62 \%$ overall palliation achieved in the control group.

Table-1: Distribution of Cases between the Two Sexes

\begin{tabular}{|c|c|c|c|c|}
\hline \multirow{2}{*}{ Sex } & \multicolumn{2}{|c|}{$\begin{array}{c}\text { Study Group } \\
\text { (50 Patients) }\end{array}$} & \multicolumn{2}{c|}{$\begin{array}{c}\text { Control Group } \\
\text { (50 Patients) }\end{array}$} \\
\cline { 2 - 5 } & No. & \% & No. & \% \\
\hline Male & 48 & $96 \%$ & 45 & $90 \%$ \\
\hline Female & 2 & $4 \%$ & 5 & $10 \%$ \\
\hline
\end{tabular}

Chi-square $=0.614$ with 1 degree of freedom; $p=0.433$

Table-2: Distribution of Cases According to the Primary site of Tumor

\begin{tabular}{|c|c|c|c|c|c|c|}
\hline \multirow{2}{*}{ Primary Site } & \multicolumn{2}{|c|}{$\begin{array}{c}\text { Study Group } \\
\text { (50 Patients) }\end{array}$} & \multicolumn{2}{c|}{$\begin{array}{c}\text { Control Group } \\
\text { (50 Patients) }\end{array}$} & $\begin{array}{c}\text { Patients in both groups } \\
\text { (100 Patients) }\end{array}$ \\
\cline { 2 - 7 } & No. & $\%$ & No. & $\%$ & No. & \% \\
\hline Oral Cavity & 25 & $50 \%$ & 20 & $40 \%$ & 45 & $45 \%$ \\
\hline Oropharynx & 12 & $24 \%$ & 13 & $26 \%$ & 25 & $25 \%$ \\
\hline Hypo pharynx & 9 & $18 \%$ & 12 & $14 \%$ & 21 & $21 \%$ \\
\hline Larynx & 4 & $8 \%$ & 5 & $10 \%$ & 9 & $9 \%$ \\
\hline Nasopharynx & 0 & $0 \%$ & 0 & $0 \%$ & 0 & $0 \%$ \\
\hline
\end{tabular}

Chi-square $=1.135$ with 3 degrees of freedom; $p=1.000$

Table-3: Distribution of Cases According to Histopathological differentiation

\begin{tabular}{|l|c|c|c|c|}
\hline \multirow{2}{*}{ Histology } & \multicolumn{2}{|c|}{$\begin{array}{c}\text { Study Group } \\
\text { (50 Patients) }\end{array}$} & $\begin{array}{c}\text { Control Group } \\
\text { (50 Patients) }\end{array}$ \\
\cline { 2 - 6 } & No. & $\mathbf{\%}$ & No. & \% \\
\hline Well Differentiated Squamous Cell Carcinoma & 20 & $40 \%$ & 12 & $24 \%$ \\
\hline Moderately Differentiated Squamous Cell Carcinoma & 17 & $34 \%$ & 18 & $36 \%$ \\
\hline Poorly/ Un Differentiated Squamous Cell Carcinoma/malignant epithelial neoplasms & 13 & $26 \%$ & 20 & $40 \%$ \\
\hline
\end{tabular}

Chi-square $=3.513$ with 2 degrees of freedom; $p=0.173$

Table-4: Distribution of Cases According to Clinical AJCC Staging

\begin{tabular}{|c|c|c|c|c|}
\hline \multirow{2}{*}{ AJCC Stage } & \multicolumn{2}{|c|}{$\begin{array}{c}\text { Study Group } \\
\text { (50 Patients) }\end{array}$} & \multicolumn{2}{c|}{$\begin{array}{c}\text { Control Group } \\
\text { (50 Patients) }\end{array}$} \\
\cline { 2 - 5 } & No. & \% & No. & \% \\
\hline III & 1 & $2 \%$ & 4 & $8 \%$ \\
\hline IVA & 8 & $16 \%$ & 18 & $36 \%$ \\
\hline IVB & 41 & $82 \%$ & 28 & $56 \%$ \\
\hline
\end{tabular}

Chi-square $=8.095$ with 2 degrees of freedom; $p=0.017$

Table-5: Symptomatic Response

\begin{tabular}{|c|c|c|c|c|c|c|c|c|}
\hline & \multicolumn{4}{|c|}{ Study Group (41 Patients) } & \multicolumn{3}{|c|}{ Control Group (46 Patients) } \\
\hline & & & \multicolumn{2}{|c|}{ Palliative Response } & & & \multicolumn{3}{c|}{ Palliative Response } \\
\hline $\begin{array}{c}\text { Presenting symptoms prior to } \\
\text { QUAD SHOT (RTOG 8502) }\end{array}$ & $\mathbf{n}$ & $\boldsymbol{\%}$ & $\begin{array}{c}\text { \# of } \\
\text { Responders }\end{array}$ & $\begin{array}{c}\text { \% of } \\
\text { Responders }\end{array}$ & $\mathbf{n}$ & $\%$ & $\begin{array}{c}\text { \# of } \\
\text { Responders }\end{array}$ & $\begin{array}{c}\% \\
\text { Responders }\end{array}$ \\
\hline Pain & 35 & $87 \%$ & 25 & $72 \%$ & 40 & $85 \%$ & 26 & $64 \%$ \\
\hline Insomnia & 36 & $88 \%$ & 21 & $56 \%$ & 36 & $90 \%$ & 22 & $60 \%$ \\
\hline Trismus & 4 & $9 \%$ & 2 & $57 \%$ & 5 & $8 \%$ & 3 & $60 \%$ \\
\hline Ryle's Tube feeding & 3 & $5 \%$ & 1 & $48 \%$ & 4 & $7 \%$ & 3 & $70 \%$ \\
\hline Weight loss & 5 & $11 \%$ & 3 & $52 \%$ & 14 & $30 \%$ & 8 & $56 \%$ \\
\hline
\end{tabular}

Chi-square $=0.037$ with 1 degree of freedom; $\mathrm{p}=0.512$, NS 
Table-6: Overall Palliation Achieved

\begin{tabular}{|c|c|c|c|c|}
\hline \multirow[t]{2}{*}{ Overall Palliation Achieved } & \multicolumn{2}{|c|}{$\begin{array}{l}\text { Study Group } \\
\text { (41 Patients) }\end{array}$} & \multicolumn{2}{|c|}{$\begin{array}{c}\text { Control Group } \\
\text { (46 Patients) }\end{array}$} \\
\hline & No. & $\%$ & No. & $\%$ \\
\hline Yes & 24 & $57 \%$ & 29 & $62 \%$ \\
\hline No & 17 & $43 \%$ & 17 & $48 \%$ \\
\hline
\end{tabular}

\section{DISCUSSION}

Palliative radiotherapy is an effective option for incurable Head and neck cancers is delivered by a variety of fractionation schedules. The 'QUAD SHOT' (RTOG 8502) palliative radiotherapy (RT) regimen offers an overall high palliative response in patients with locally advanced Head and Neck cancers who are not suitable for curative treatment with limited life expectancy.

Symptomatic response was subjective relief of symptoms like pain, insomnia, trismus, requirement of feeding tube placement and history of weight loss. The clinical response rates (LRC $=$ locoregional control) obtained after 6 months of treatment follow up reveals that complete response (CR) was achieved in 1 patient $(2 \%)$ in the control group and none in the study group. The partial response (PR) rates were 28 patients $(69 \%)$ in the study group and 23 patients (72\%) in the control group. Overall response rates (CR+PR) was $69 \%$ in study group and $74 \%$ in the control group and was statistically non-significant $\quad(p=0.634) .57 \% \quad(24$ patients) had an overall palliative response in the study group while $62 \%$ (29 patients) in the control group which is statistically non significant in both groups $(\mathrm{p}=0.834)$. The overall palliative response achieved in both groups in our study is comparable to achieved by Corry et al. [15]. The study consisted of $14 \mathrm{~Gy}$ in four fractions, given twice a day and at least 6 hours apart, for 2 consecutive days. The regimen was repeated at 4 weekly intervals for a further two courses i.e. upto 42 Gy in 12 fractions, if there was no tumour progression. The aims of the study were to evaluate the rate of tumor response (primary) and toxicity, quality of life (QoL) and survival in such patients (secondary). Both compliance rate to all the three cycles and objective response rate was $53.3 \%$. Median overall survival was 5.7 months, median progression free survival was 3.1 months. Improvement in QoL was noted in $44 \%$ of the patients. Chen et al. [16] reviewed the University of California Davis School of Medicine experience in 60 patients who underwent a variety of hypo fractionated palliative regimens for recurrent or incurable head and neck cancers including the RTOG 8502, 70 Gy in 35 fractions, $30 \mathrm{~Gy}$ in 10 fractions, $37.5 \mathrm{~Gy}$ in 15 fractions, and $20 \mathrm{~Gy}$ in 5 fractions. The results were generally superior to the other fractionation schedules reviewed which reported palliative response ranging from $60-$ $86 \%$. Lok et al.[17] have reported that $37 \%$ of their patients completed at least three cycles while $65 \%$ had a palliative response. Median overall survival was 5.67 months. On survival analysis, palliative response $(p<$ $0.001), \operatorname{KPS} \geq 70(P=0.001)$, and greater number of cycles $(p=0.02)$ remained independent predictors of improved survival. Das, et al. [18] treated 36 LASCCHN cancer patients with 40 Gy in 10 fractions with 2 fractions per week. Compliance rate was $73 \%$ and the median overall survival of the cohort was 7 months. The "Hypo Trial" conducted by Porceddu and Colleagues[19] treated 35 incurable head and neck cancer patients with the goal of $30 \mathrm{~Gy}$ in 5 fractions with 2 fractions per week. Thirty-one $(88 \%)$ of the patients received at least $30 \mathrm{~Gy}$. Overall $80 \%$ of patients experienced an overall objective response.

Mudgal et al. [20] observed good objective response in $82.6 \%$ and $84.7 \%$ of patients at primary and nodal sites, respectively. Jakhar et al. [21] performed a pilot study to evaluate the effect of an accelerated hypofractionated 4 days schedule (octa shot) in providing palliation to such advanced cases of head and neck cancer. After completion of radiotherapy, first response evaluation done at 15 th day showed $\geq 50 \%$ objective response in 14 patients. At 1 month, this response increased to $\geq 75 \%$ in 16 patients and $50 \%$ $75 \%$ in three patients. None of the patients had disease progression. Improvement in symptoms was reported with respect to pain and dysphagia by patients subjectively. The overall palliative response rates achieved in our study was comparable to above mentioned various standard hypofractionated palliative regimen.

\section{Conclusion}

We conclude that Two weeks gap in 'QUAD SHOT' (RTOG 8502) radiotherapy regimen can be used in locally advanced Head and Neck cancers to shorten overall treatment time without compromising overall palliation achieved in terms of symptomatic response and locoregional control (LRC) with manageable toxicities. Larger prospective randomized studies with longer duration of follow up may be needed for strong evaluation of efficacy, toxicity profile and to draw inference on locoregional control (LRC), Disease Free Survival (DFS), median survival and overall survival (OS).

\section{REFRENCES}

1. Katoch VM. Three-year report of population based cancer registries 2012-2014. Bengaluru, India: National Centre for Disease Informatics and 
Research National Cancer Registry Programme. 2016.

2. Ferlay J, Parkin DM, Pisani PG. Cancer incidence, mortality and prevalence worldwide, International Agency for Research on cancer. IARC Cancer Base. 2002(5).

3. Johnston LD, O'Malley PM. The recanting of earliar reported drug use by young adults. NIDA Res Monogr. 1997; 167:59-80.

4. Hashibe M, Daniel E, Ford MD, Zuo-Feng Z. The Journal of Clinical Pharmacology. 2002;42(11): 103S-7S.

5. Donald PJ. Marijuana smoking--possible cause of head and neck carcinoma in young patients. Otolaryngol Head Neck Surg. 1986 Apr;94(4):517-21.

6. Franceschi S, Levi F, La Vecchia C, Conti E, Dal Maso L, Barzan L, Talamini R. Comparison of the effect of smoking and alcohol drinking between oral and pharyngeal cancer. International journal of cancer. 1999 Sep 24;83(1):1-4.

7. Blot WJ, McLaughlin JK, Winn DM, Austin DF, Greenberg RS, Preston-Martin S, Bernstein L, Schoenberg JB, Stemhagen A, Fraumeni JF. Smoking and drinking in relation to oral and pharyngeal cancer. Cancer research. 1988 Jun 1;48(11):3282-7.

8. Varela-Lema L, Ruano-Ravina A, Crespo MA, Barros-Dios JM: Tobacco consumption andoral and pharyngeal cancer in a Spanish male population. Cancer Lett. 2009, 288:28-35.

9. Kune GA, Kune S, Field B, Watson LF, Cleland H, Merenstein D, Vitetta L. Oral and pharyngeal cancer, diet, smoking, alcohol, and serum vitamin a and $\beta$ - carotene levels: A case- control study in men.

10. Soler M, Bosetti C, Franceschi S, Negri E, Zambon P, Talamini R, Conti E, La Vecchia C. Fiber intake and the risk of oral, pharyngeal and esophageal cancer. International journal of cancer. 2001 Feb 1;91(3):283-7.

11. Huebner WW, Schoenberg JB, Kelsey JL, Wilcox HB, McLaughlin JK, Greenberg RS, PrestonMartin S, Austin DF, Stemhagen A, Blot WJ, Winn DM. Oral and pharyngeal cancer and occupation: a case-control study. Epidemiology. 1992 Jul 1:300-9.

12. Winquist E, Agbassi C, Meyers BM, Yoo J, Chan KK. Systemic therapy in the curative treatment of head and neck squamous cell cancer: a systematic review. Journal of Otolaryngology-Head \& Neck Surgery. 2017 Dec;46(1):29.

13. Michael Laursen, Lena Specht, Claus AndrupKristensen, Anita Gothelf, Mogens Bernsdorf, Ivan Vogelius An Extended Hypofractionated Palliative Radiotherapy Regimen for Head and Neck Carcinomas,https://www.ncbi.nlm.nih.gov/pmc/art icles/PMC6004383/\#

14. National Comprehensive Cancer Network $(\mathrm{NCCN})$. Head and Neck Cancer (Version 2, 2017).

15. Corry J, Peters LJ, D'Costa I, Milner AD, Fawns $\mathrm{H}$, Rischin D, Porceddu S. The 'QUAD SHOT'a phase II study of palliative radiotherapy for incurable head and neck cancer. Radiotherapy and oncology. 2005 Nov 1;77(2):137-42.

16. Chen AM, Vaughan A, Narayan S, Vijayakumar S. Palliative radiation therapy for head and neck cancer: toward an optimal fractionation scheme. Head \& Neck: Journal for the Sciences and Specialties of the Head and Neck. 2008 Dec;30(12):1586-91.

17. Lok BH, Jiang G, Gutiontov S, Lanning RM, Sridhara S, Sherman EJ, Tsai CJ, McBride SM, Riaz N, Lee NY. Palliative head and neck radiotherapy with the RTOG 8502 regimen for incurable primary or metastatic cancers. Oral oncology. 2015 Oct 1;51(10):957-62.

18. Das S, Thomas S, Pal SK, Isiah R, John S. Hypofractionated palliative radiotherapy in locally advanced inoperable head and neck cancer: CMC Vellore experience. Indian journal of palliative care. 2013 May;19(2):93.

19. Porceddu \& Colleagues. Hypo Trial Hypofractionated palliative regimens. J Can Res Ther. 2014;15:428-31.

20. Mudgal A, Arya AK, Yadav I, Chaudhary S. Role of hypofractionated palliative radiotherapy in patients with stage four head-and-neck squamous cell carcinoma. J Can Res Ther. 2019;15:528-32.

21. Jakhar SL, Purohit R, Solanki A, Murali P, Kothari T, Sharma N, Kumar HS. Accelerated hypofractionation (OCTA SHOT): Palliative radiation schedule in advanced head and neck carcinoma. Journal of cancer research and therapeutics. 2017 Oct 1;13(6):943. 